\title{
INNOVATION OF PHYSICAL EDUCATION AT TECHNICAL UNIVERSITY IN ZVOLEN
}

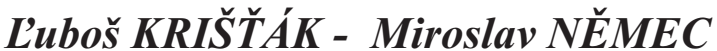

\begin{abstract}
The article deals with innovative methods of physics education in physical subjects. There is described and evaluated educational experiment at the Faculty of Wood Sciences and Technology in Technical University in Zvolen, where we measured the impact of innovative methods for learning outcomes of students in physics. The conclusion summarizes the results of this experiment.
\end{abstract}

Key words: Technical University, physics, teaching, ICT.

\section{INOVÁCIA FYZIKÁLNEHO VZDELÁVANIA NA TECHNICKEJ UNIVERZITE VO ZVOLENE}

Resumé: Článok sa zaoberá inovatívnymi metódami vzdelávania vo fyzikálnych predmetoch a pedagogickým výskumom, ktorý sme uskutočnili na Drevárskej fakulte Technickej univerzity vo Zvolene, kde sme zistovali vplyv inovativnych didaktických metód na výsledky študentov v predmete Fyzika. V závere sumarizujeme výsledky tohto výskumu.

Kl'účové slová: Technická univerzita, technické vzdelávanie, fyzika, vyučovanie, IKT.

\section{1 Úvod}

$\mathrm{V}$ nedávnej minulosti prebehla reforma vysokého školstva, pričom jedným $\mathrm{z}$ jej výsledkov bol prechod na trojstupňový systém vysokoškolského vzdelávania. Zo zavedených zmien vyplynuli určité systémové zmeny, ktoré bolo nutné vykonat' $\mathrm{v}$ rámci jednotlivých študijných programov. V rámci týchto zmien došlo $\mathrm{k}$ redukcii časovej dotácie niektorých premetov, pričom to neobišlo ani fyzikálne predmety bakalárskeho štúdia. Na technických univerzitách patria fyzikálne predmety k základným predmetom, na ktoré následne nadväzujú d'alšie technické disciplíny. Práve tieto fyzikálne predmety sú akýmsi základným nástrojom pre pochopenie väčšiny technických predmetov.

Slovensko v tomto období zároveň prechádza reformou regionálneho školstva, ktorej základom je prechod na tvorivo-humánne školstvo s orientáciou na študenta [1]. V novej koncepcii sú prírodovedné a technické predmety potláčané do úzadia $[2,3,4]$. Najviac sa redukcia hodín dotkla práve fyziky, čo bude mat' negatívny dosah najmä na vysokých školách prírodovedných a technických zameraní. Tento stav je čiastočne výsledkom nedostatočnej komunikácie medzi strednými a vysokými školami a najmä potrebami praxe. Okrem toho v súčasnosti je trendom, aby sa zvyšoval počet vysokoškolsky vzdelaných l'udí. Z toho vyplýva, že sa na vysoké školy hlásia študenti z takmer všetkých typov stredných škôl, pričom ich úroveň vedomostí po príchode na vysokú školu je na rôznej úrovni. Až na niekol'ko výnimiek, väčšinou $\mathrm{z}$ gymnázií, sú vedomosti študentov z fyziky a matematiky po príchode na vysokú školu z roka na rok slabšie [5]. Predpokladáme, že na základe novej reformy regionálneho školstva bude tento trend pokračovat', pričom je nutné hl'adat' riešenia tejto situácie. Vzhl'adom $\mathrm{k}$ zhoršujúcej sa úrovni vedomostí študentov z prírodovedných predmetov po príchode na vysokú školu a vzhl'adom $\mathrm{k}$ redukcii počtu hodín fyzikálnych predmetov na vysokých školách je potreba hl'adat' špecifické riešenia.

Výučba fyzikálne zameraných predmetov na Technickej univerzite vo Zvolene má celý rad špecifík, ktoré vychádzajú $\mathrm{z}$ požiadaviek jednotlivých študijných zameraní jej jednotlivých fakúlt. Jedno však majú spoločné všetky fakulty a odbory a to je výrazná redukcia počtu hodín fyzikálnych predmetov po prechode na trojstupňový systém vzdelávania. V bakalárskom stupni štúdia je väčšinou na troch fakultách na Technickej univerzite vo Zvolene, na ktorých sa fyzika v prvom ročníku bakalárskeho stupňa štúdia vyučuje, pre základný kurz fyziky vyhradený len jeden semester $\mathrm{s}$ rozsahom dve hodiny prednášok a dve hodiny cvičení týždenne, aj to $\mathrm{v}$ prvom semestri, ked' študenti nemajú absolvovaný kurz vyššej matematiky [6]. Vzniká tým potreba 
vytvorenia nových učebných materiálov, ktorých obsah bude $\mathrm{v}$ súlade so študijnými programami a budú zároveň modernou a pútavou formou prezentovat' poznatky $\mathrm{v}$ danej oblasti. Našim ciel'om bolo preto vytvorenie kompletných študijných materiálov, ktoré sú $\mathrm{v}$ súlade so študijnými programami Technickej univerzite vo Zvolene, a okrem toho na Univerzite Mateja Bela v Banskej Bystrici, ako aj Slovenskej pol'nohospodárskej univerzite $\mathrm{v}$ Nitre, kde je v rámci bakalárskeho stupňa štúdia možné študovat' obsahovo podobné študijné odbory. Okrem vytvorenia nových materiálov bolo našim ciel'om pomocou pedagogického výskumu ukázat', že využívanie problémových úloh a častejšie uplatnenie experimentálnych aktivít na cvičeniach pomôže $\mathrm{k}$ lepším vedomostiam študentov z fyziky. Experimentmi a ich didaktickými aspektmi $v$ rôznych fyzikálne zameraných predmetoch na TU vo Zvolene sa zaoberajú práce: $[7,8,9,10]$.

\section{Výskum}

\section{Ciel'om}

vzdelávacích

\section{výskumu} výsledkov

bola komparácia dosiahnutých vo vyučovacom procese, $\mathrm{v}$ ktorom bol kladený zvýšený dôraz na využívanie kvalitatívnych úloh a výraznejšie využívanie experimentálnych aktivít $\mathrm{v}$ porovnaní s vyučovacím procesom, kde sa vyučovalo klasickým, doteraz zaužívaným spôsobom. Porovnávala sa vedomostná úroveň z preberaného učiva, t.j. študenti pred a po absolvovaní výučby fyziky v prvom semestri absolvovali didaktické testy.

Pedagogický experiment bol realizovaný na Technickej univerzite počas študijného roka 2009/2010 na drevárskej fakulte (DF). Išlo o fyzikálny predmet $\mathrm{v}$ prvom ročníku bakalárskeho stupňa štúdia s dotáciou v semestri dve hodiny prednášok a dve hodiny cvičení. Podstatná čast' obsahovej stránky fyziky v prvom ročníku na našej univerzite je zameraná na opakovanie a prehlbovanie gymnaziálneho učiva, ktoré je primerane rozšírené o vyššiu fyziku, ktorú by mali študenti prvého ročníka vysokej školy zvládat'. Primárnym ciel’om predmetu fyziky v prvom ročníku na Technickej univerzite vo Zvolene je zmazat' rozdiely vo vedomostnej úrovni študentov spôsobené rôznym stupňom fyzikálneho vzdelania získaného na stredných školách. Z trinástich cvičení počas semestra je sedem teoretických, to znamená venovaných riešeniu fyzikálnych úloh a šest' je praktických, na ktorých študenti vykonávajú laboratórne merania.
V letnom semestri sa na DF výskumu zúčastnili štyri kontrolné a štyri experimentálne skupiny. V prípade kontrolných tried prebiehala výučba klasickým, u nás zaužívaným spôsobom. Klasickým spôsobom máme v tomto prípade na mysli $v$ rámci jedného semestra trinást' prednášok a trinást' cvičení, $\mathrm{z}$ ktorých sedem je teoretických a v tomto prípade zameraných na počítanie príkladov $\mathrm{z}$ jednotlivých fyzikálnych oblastí preberaných na prednáškach a šest' praktických cvičení (laboratórnych meraní), kde sú študenti rozdelení do skupín po cca 5 študentov, pričom každá zo skupín počas jedného praktického cvičenia absolvuje jedno laboratórne meranie. Všetkých šest' laboratórnych meraní, ktoré študenti počas semestra vykonali je klasických, t.j. bez podpory informačných a komunikačných technológií.

$\mathrm{V}$ experimentálnych triedach absolvovali študenti takisto trinást' prednášok a trinást' cvičení, pričom došlo k niekol'kým výrazným zmenám v organizácii vyučovania. V prípade praktických cvičení došlo $\mathrm{k}$ podstatnej zmene tým, že niektoré klasické laboratórne merania boli nahradené počítačom podporovanými laboratórnymi meraniami. Používaním dostupným počítačom podporovaných metód (napr. matematické modelovanie, Fourierova analýza, atd'.) sa podstatne zmenil aj spôsob spracovania nameraných údajov $[11,12]$. Zvyšnú čast' vytvoreného časového priestoru sme na každom laboratórnom meraní so študentmi venovali videoexperimentom, ktoré obsahovali rôzne fyzikálne javy súvisiace $\mathrm{s}$ odprednášanou tematikou $\mathrm{v}$ danom období. V prípade teoretických cvičení došlo k zmene po obsahovej stránke. Kým v kontrolných triedach boli počítané kvantitatívne príklady z fyziky, v experimentálnych triedach sme sa zamerali popri kvantitatívnych úlohách najmä na kvalitatívne úlohy. Pri každej kvalitatívnej úlohe bol vykonaný rozbor, pričom pri úlohách bola snaha zamerat' sa najmä na fyzikálnu podstatu veci. Pri náročnejších kvalitatívnych úlohách sme opät’ využili videoexperimenty $\mathrm{k}$ jednotlivým kvantitatívnym úlohám, čo študentom výrazne pomáhalo pri riešení fyzikálnych problémov. Zároveň boli na týchto cvičeniach vykonávané demonštračné a študentské experimenty. Pri všetkých experimentoch, ktoré boli realizované $\mathrm{v}$ experimentálnych triedach, dostali študenti $\mathrm{k}$ dispozícii študentské pracovné listy a pedagógovia mali k dispozícii metodické listy pre pedagógov. Prednášky mali kontrolné 
aj experimentálne skupiny rovnaké $\mathrm{v}$ rámci jednotlivých fakúlt.

\subsection{Vyhodnotenie vstupných testov}

$\mathrm{Na}$ zist'ovanie vedomostí experimentálnych a kontrolných

žiakov tried pred začatím experimentovania sme použili pretest, konkrétne neštandardizovaný didaktický test (rovnaký vo všetkých skupinách), ktorým bola testovaná úroveň zapamätania, pochopenia daného učiva a schopnost' riešit' príklady zo stredoškolskej fyziky [13, 14]. Didaktický test bol vytvorený pre dve skupiny $\mathrm{A}$ a $\mathrm{B}$, testy boli obsahovo rovnaké, líšili sa len poradím úloh. Test žiaci vykonali v prvom týždni semestra, pričom test obsahoval 30 úloh a časová dížka vypracovania testu bola 35 minút.

Čo sa týka validity testu, náš test bol neštandardizovaný a na posúdenie jeho obsahovej validity sme použili index obtiažnosti $\left(\mathbf{p}_{\mathbf{i}}\right)$. Spol'ahlivost' didaktického testu okrem validity posudzujeme aj na základe jeho reliability (r). V našej práci sme na výpočet reliability $r$ použili tzv. Cronbachovu metódu. Okrem toho sme určili vel'kost' smerodajnej chyby merania $s_{e}$ a smerodajnú chybu priemeru $s_{x}$. Charakteristiky jednotlivých skupín uvádzame v Tab. 1. Za každú úlohu v teste bol jeden bod, celkové dosiahnutel'né bodové hodnotenie bolo teda 30 bodov. Charakteristiky pretestu pre jednotlivé skupiny uvádzame v tabul'ke 1.

Tab. 1: Charakteristiky jednotlivých vstupných didaktických testov

\begin{tabular}{|l|c|c|}
\hline & DFLE & DFLK \\
\hline $\begin{array}{l}\text { Počet študentov } \\
\text { riešiacich test }\end{array}$ & 74 & 74 \\
\hline $\begin{array}{l}\text { Priemerné skóre } \\
(\bar{x})\end{array}$ & 6,26 & 6,52 \\
\hline $\begin{array}{l}\text { Smerodajná } \\
\text { odchýlka (s) }\end{array}$ & 3,02 & 3,77 \\
\hline $\begin{array}{l}\text { Index } \\
\left.\text { obtiažnosti ( } \mathbf{p}_{\mathbf{i}}\right)\end{array}$ & 0,21 & 0,20 \\
\hline $\begin{array}{l}\text { Koeficient } \\
\text { reliability (r) }\end{array}$ & 0,51 & 0,70 \\
\hline $\begin{array}{l}\text { Smerodajná } \\
\text { chyba merania } \\
\left(\mathbf{s}_{\mathbf{e}}\right)\end{array}$ & 1,48 & 2,06 \\
\hline $\begin{array}{l}\text { Smerodajná } \\
\text { chyba priemeru } \\
\left(\mathbf{s}_{\mathbf{x}}\right)\end{array}$ & 0,35 & 0,44 \\
\hline
\end{tabular}

Použili sme zložité skórovanie, a to najmä pri úlohách zameraných na nešpecifický transfer. Namiesto priemerného skóre sme určovali vážené skóre testu. Pri kategorizácii jednotlivých úloh sme vychádzali z taxonómie B. Niemierka: zapamätanie, porozumenie, špecifický transfer a nešpecifický transfer [13]. Na základe tejto klasifikácie sme jednotlivým úlohám pridelili váhu významu. Nakol'ko sme použili zložité skórovanie, bolo nevyhnutné tento rôzny počet bodov dostat' na jednu úroveň - zrovnocennit' ich, čo sme urobili tak, že pre každú úlohu DT sme vypočítali relatívnu percentuálnu úspešnost' riešenia

$p_{i, j}=\frac{x_{i, j}}{x_{\max , j}} 100 \%$

kde

$p_{i, j}$ je percentuálna (relatívna úspešnost') riešenia $\mathrm{j}$ - tej úlohy DT $\mathrm{i}$ - tým študentom

$x_{i, j}$ je počet bodov, ktoré získal i - ty študent za $\mathrm{j}$ - tú úlohu

$x_{\max , j}$ je maximálne dosiahnutel'ný počet bodov za j- tu úlohu DT.

Vážené skóre testu i- teho študenta sme vypočítali:

$p_{i}^{v}=\frac{\sum x_{i, j} \cdot v_{j}}{\sum v_{j}}$,

kde $v_{j}$ predstavuje váhu významu j- tej úlohy didaktického testu. Okrem toho sme v prípade každej skupiny určili základné štatistické charakteristiky - smerodajnú odchýlku, variačné rozpätie a variačný koeficient.

$\mathrm{Na} \mathrm{DF}$ sa v letnom semestri študijného roka 2009/2010 výskumu zúčastnili dve kontrolné skupiny (spolu 74 študentov) a dve experimentálne skupiny (spolu 74 študentov). $\mathrm{Na}$ zist'ovanie vedomostí študentov experimentálnych a kontrolných tried sme pred začiatkom experimentovania opät' použili vstupný didaktický test. Charakteristiky didaktického testu DFZ 2009/2010 sú uvedené v Tab. 2. 
Tab. 2: Štatistické charakteristiky vstupného didaktického testu

\begin{tabular}{|l|c|c|}
\hline & DFLE & DFLK \\
\hline $\begin{array}{l}\text { Počet žiakov } \\
\text { riešiacich test }\end{array}$ & 74 & 74 \\
\hline $\begin{array}{l}\text { Relatívne skóre } \\
\left(\mathrm{p}^{\mathrm{v}} \text { priemer) }\right.\end{array}$ & 18,75 & 19,72 \\
\hline Medián (p) & 17,65 & 16,18 \\
\hline $\begin{array}{l}\text { Smerodajná } \\
\text { odchýlka (s) }\end{array}$ & 10,36 & 12,93 \\
\hline $\begin{array}{l}\text { Variačné } \\
\text { rozpätie }\end{array}$ & 63,91 & 58,82 \\
\hline $\begin{array}{l}\text { Variačný } \\
\text { koeficient }\end{array}$ & 55,26 & 65,60 \\
\hline
\end{tabular}

\subsection{Vyhodnotenie výstupných testov}

Charakteristiky jednotlivých skupín výstupného didaktického testu uvádzame v Tab. 3. Vo všetkých skupinách žiaci absolvovali ten istý didaktický test, ktorý obsahoval 30 úloh. Maximálny počet bodov bol 30 .

Tab. 3: Charakteristiky jednotlivých výstupných didaktických testov pre kontrolné a experimentálne skupiny

\begin{tabular}{|c|c|c|}
\hline & DFLE & DFLK \\
\hline $\begin{array}{c}\text { Počet študentov } \\
\text { riešiacich test }\end{array}$ & 74 & 74 \\
\hline $\begin{array}{c}\text { Priemerné skóre } \\
(\bar{x})\end{array}$ & 19,09 & 15,7 \\
\hline $\begin{array}{c}\text { Smerodajná } \\
\text { odchýlka (s) }\end{array}$ & 7,14 & 5,71 \\
\hline $\begin{array}{c}\text { Index obtiažnosti } \\
\left(\mathbf{p}_{\mathbf{i}}\right)\end{array}$ & 0,63 & 0,48 \\
\hline $\begin{array}{c}\text { Koeficient } \\
\text { reliability (r) }\end{array}$ & 0,90 & 0,81 \\
\hline $\begin{array}{c}\text { Smerodajná chyba } \\
\left.\text { merania (s } \mathbf{s}_{\mathbf{e}}\right)\end{array}$ & 2,26 & 2,49 \\
\hline $\begin{array}{c}\text { Smerodajná chyba } \\
\text { priemeru }\left(\mathbf{s}_{\mathbf{x}}\right)\end{array}$ & 0,84 & 0,67 \\
\hline
\end{tabular}

Jednotlivé štatistické charakteristiky didaktického testu sme použili rovnaké ako pri vstupnom teste. V úvode testu vo všetkých skupinách bola stanovená nulová hypotéza

$\mathbf{H}_{\mathbf{0}}: \bar{p}_{1}(\mathrm{KT})=\bar{p}_{2}(E T)$, pričom hladinu významnosti sme zvolili $\alpha=0,05$. V prípade zamietnutia nulovej hypotézy bola prijatá alternatívna hypotéza

$\mathbf{H}_{1}: \quad \bar{p}_{1}(K T) \neq \bar{p}_{2}(E T) \quad, \quad$ resp. $\mathrm{H}_{1}:$ $\bar{p}_{1}(K T)<\bar{p}_{2}(E T)$. Ked'že sme predpokladali, že $\mathrm{v}$ experimentálnych triedach dosiahnu študenti vyššiu vedomostnú úroveň z fyziky, formulovali sme otázku ako jednostranný test. Pri tomto predpoklade sme vychádzali z pilotného prieskumu, ktorý sme uskutočnili v roku 2008/2009, rovnako aj po konzultáciách s vyučujúcimi na jednotlivých fakultách.

Na overenie vyslovených hypotéz sme zvolili test rozdielu aritmetických priemerov. Vychádzali sme z $t$ - rozdelenia, kde $t$ vypočítame podl'a vzt’ahu

$t=\frac{\bar{p}_{1}-\bar{p}_{2}}{s_{v}} \sqrt{\frac{n_{1} n_{2}}{n_{1}+n_{2}}}$.

Vypočítanú hodnotu $t$ porovnávame s kritickou hodnotu $t_{\alpha, f}$. Vo vzt'ahu pre testovaciu veličinu $t$ vystupuje $s_{v}$, čo je vážený priemer oboch smerodajných odchýliek $\left(_{1}\right.$ pre experimentálnu skupinu a $s_{2}$ pre kontrolnú skupinu) a vypočítame ho zo vzt’ahu:

$s_{v}=\sqrt{\frac{\left(n_{1}-1\right) s_{1}^{2}+\left(n_{2}-1\right) s_{2}^{2}}{n_{1}+n_{2}-2}}$,

kde $n_{1}$ a $n_{2}$ sú počty študentov $\mathrm{v}$ experimentálnej a v kontrolnej skupine a v menovateli je výraz, ktorý označujeme ako $f$ a nazývame stupeň vol'nosti $f=n_{1}+n_{2}-2$.

Charakteristiky didaktického testu sú uvedené v Tab.4.

Tab. 4: Štatistické charakteristiky výstupného didaktického testu

\begin{tabular}{|l|c|c|}
\hline & DFLE & DFLK \\
\hline $\begin{array}{l}\text { Počet študentov } \\
\text { riešiacich test }\end{array}$ & 74 & 74 \\
\hline $\begin{array}{l}\text { Relatívne skóre } \\
\left(p^{v} \text { priemer) }\right.\end{array}$ & $61,86 \%$ & $49,88 \%$ \\
\hline Medián (p) & $66,44 \%$ & $47,26 \%$ \\
\hline $\begin{array}{l}\text { Smerodajná } \\
\text { odchýlka (s) }\end{array}$ & $23,33 \%$ & $19,11 \%$ \\
\hline $\begin{array}{l}\text { Variačné } \\
\text { rozpätie }\end{array}$ & $84,93 \%$ & $83,56 \%$ \\
\hline $\begin{array}{l}\text { Variačný } \\
\text { koeficient }\end{array}$ & $37,71 \%$ & $38,32 \%$ \\
\hline $\begin{array}{l}\text { Vážený priemer } \\
\text { smer. odchýliek } \\
\left(\mathrm{s}_{\mathrm{v}}\right)\end{array}$ & 21,32 \\
\hline $\begin{array}{l}\text { Testovacia } \\
\text { veličina (t) }\end{array}$ & 3,42 \\
\hline $\begin{array}{l}\text { Kritická hodnota } \\
\left(\mathrm{t}_{0,05,146)}\right)\end{array}$ \\
\hline
\end{tabular}


Na základe kritéria $|t|>t_{0,05 ; 113}$ môžeme nulovú hypotézu $H_{0}$ zamietnut' a prijat' alternatívnu hypotézu $H_{1}$ : Priemerné skóre študentov experimentálnej skupiny DFLE je vyššie ako priemerné skóre študentov kontrolnej skupiny DFLK.

$\mathrm{Na}$ lepšie zobrazenie rozloženia dosiahnutých výsledkov u študentov použijeme frekvenčnú tabul'ku Tab. 5. a na základe tejto tabul'ky zostrojený Graf 1. Čo sa týka hraničných hodnôt vo frekvenčnej tabul'ke, opät' sme ako minimálnu hodnotu použili najnižšie dosiahnuté skóre v oboch skupinách (DFLE, DFLK), najvyššia hodnota vo frekvenčnej tabul'ke bolo najvyššie dosiahnuté skóre $\mathrm{v}$ teste $\mathrm{v}$ oboch skupinách.

Tab. 5: Frekvenčná tabul'ka pre výstupný didaktický test $-D F L$

\begin{tabular}{|c|c|c|c|}
\hline & $\begin{array}{c}\text { Skóre } \\
{[\%]}\end{array}$ & $\begin{array}{c}\text { DFLE } \\
{[\%]}\end{array}$ & $\begin{array}{c}\text { DFLK } \\
{[\%]}\end{array}$ \\
\hline 1. & $0,0-20,0$ & 2,38 & 4,05 \\
\hline 2. & $20,1-40,0$ & 12,70 & 31,08 \\
\hline 3. & $40,1-60,0$ & 7,94 & 36,49 \\
\hline 4. & $60,1-80,0$ & 18,25 & 20,27 \\
\hline 5. & $80,1-100,0$ & 58,73 & 8,11 \\
\hline
\end{tabular}

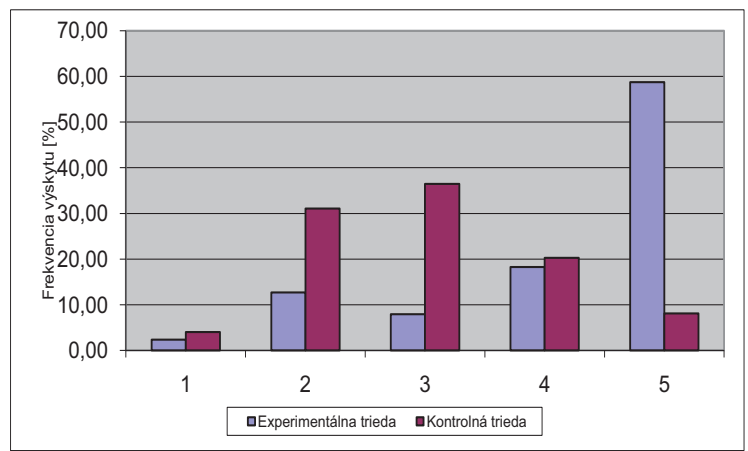

Graf 1: Výsledky výstupného didaktického testu $v$ kontrolnej a experimentálnej triede (Príklad: skóre $80-100 \%$ dosiahlo 58,73\% študentov experimentálnej skupiny a $8,11 \%$ študentov kontrolnej skupiny).

$\mathrm{Na}$ základe frekvenčnej tabul'ky a k nej zodpovedajúcemu grafu môžeme konštatovat', že relatívne vážené skóre $\mathrm{v}$ experimentálnej skupine (DFLE) je vyššie ako v kontrolnej skupine (DFLK). Posun krivky, ktorá charakterizuje rozloženie výkonu študentov v experimentálnych skupinách v porovnaní s krivkou, ktorá charakterizuje rozloženie výkonu $\mathrm{v}$ kontrolných skupinách nastal $\mathrm{k}$ vyšším hodnotám dosiahnutého skóre, čím sa potvrdzuje alternatívna hypotéza. Z toho môžeme konštatovat', že dôraz kladený na experimentálnu činnost' študentov a kvalitatívne úlohy vo vyučovacom procese z fyziky mal pozitívny vplyv na vedomostnú úroveň u študentov experimentálnych tried. Vplyv rozdielnej vedomostnej úrovne $\mathrm{z}$ fyziky u študentov kontrolných a experimentálnych tried pred testovaním bol minimálny, čo sme ukázali v predchádzajúcej kapitole.

\section{Záver}

Pokúsime sa zhrnút' výsledky získané počas pedagogického experimentu (pri vyhodnocovaní didaktických testov i dotazníkov) do niekol'kých bodov:

1. Ukázalo sa, že použitie nových študijných materiálov spolu s väčším dôrazom kladeným na využívanie problémových úloh a experimentálnych aktivít pomohlo k zvýšeniu vedomostnej úrovne študentov z fyziky. Týmto sa potvrdila hypotéza $H_{1}$. Toto tvrdenie opierame o výsledky pedagogického experimentu. Po absolvovaní predmetu Fyzika boli študenti experimentálnych i kontrolných tried podrobení neštandardizovanému didaktickému testu. $Z$ výsledkov tohto testu vyplýva, že priemerné výsledky študentov v experimentálnych skupinách boli výrazne lepšie ako u žiakov v kontrolných skupinách

2. Implementácia kvalitatívnych úloh vo vyučovaní fyziky prispieva k uplatňovaniu základných didaktických zásad, napr. zvyšuje sa názornost' preberaného učiva (zásada názornosti), žiaci sú nútení aktívnejšie sa podiel'at' na vyučovacom procese (zásada aktivity). Návyky, skúsenosti a zručnosti získané pri riešení kvalitatívnych úloh budú môct' študenti (aj tí, ktorí sa nebudú fyzikou bližšie zaoberat') využit' aj v d'alšom štúdiu na vysokej škole.

3. Z pozorovania vyplýva, že študenti sú pri kvalitatívnych úlohách, najmä tých, ktoré sú úzko spojené s praxou a každodenným životom, pozornejší a aktívnejší. Do ich riešenia sa zapájajú aj študenti, ktorí nemajú o fyziku vel'ký záujem a majú z nej horšie výsledky.

4. Využitie experimentov vo vyučovaní zvyšuje názornost' prebraného učiva, zvyšuje pozornost' študentov, núti ich samostatne pracovat' a mysliet' a pomáha poukazovat' na prepojenie fyzikálnej 
teórie s každodenným životom v prírode technike i spoločnosti. Niektoré experimenty boli vykonané reálne, niektoré boli použité ako video experimenty. Študenti boli aktívne zapájaní vo všetkých fázach experimentovania a pri video experimentoch učitel' vhodne zastavoval projekciu, doplńal vlastným komentárom, prípadne diskutoval so študentmi.

\section{Literatúra}

[1] Koncepcia rozvoja výchovy a vzdelávania v Slovenskej republike na najbližších $15-20$ rokov (projekt „MILÉNIUM“) [online]. Dostupné na internete: $<$ http://www.education.gov.sk $>$.

[2] HOLEC, S. Posilnenie experimentálnej bázy výučby prírodovedných predmetov. In: Vybrané problémy $z$ didaktiky prírodovedných predmetov. Banská Bystrica: Univerzita Mateja Bela, Fakulta prírodných vied, Projekt Tempus 0927295, 1999, s. 5 - 36. ISBN 80-8055-151-0.

[3] STEBILA, J. New forms of natural sciences education in the context of lower secondary education in the slovak republik. In: Communications. Scientific letters of the university of Zilina. ISSN 1335-4205 (print)

[4] Hockicko, P. Nontraditonal approach to studying science and technology. In: Communications. Scientific letters of the university of Zilina. ISSN 1335-4205 (print)

[5] Štátny vzdelávací program pre gymnáziá. Bratislava, 2008. [online]. Dostupné na internete:

http://www.statpedu.sk/buxus/generate page.ph p?page $\mathrm{id}=1221$

[6] DANIHELOVÁ, A. Fyzika a jej miesto v nových študijných programoch na Technickej univerzite vo Zvolene. In Transformácia starých študijných odborov na nové princípy trojstupňového vysokoškolského vzdelávania: Medzinárodné sympózium, Starý SmokovecTatry. Zvolen: TU vo Zvolene, 2006, s. 17 - 21. ISBN 80-228-1675-2

[7] DANIHELOVÁ, A. Acoustics in Education and Research at the Faculty of Wood Sciences and Technology TU in Zvolen. In.: Proceedings of the $4^{\text {th }}$ International Conference on Physics
[8] Teaching in Engineering Education PTEE 2005, Brno, 2005, s. 5 - 4, ISBN 80-903063-6-5 [9] NĚMEC, M. Vplyv kvalitatívnych úloh z akustiky na vedomosti študentov - 1/0841/08. In: Záujmová činnost' žiakov - stav, problémy, trendy [elektronický zdroj] : medzinárodná vedecko-odborná konferencia : 27.11.28.11.2008, Prešov : Katedra fyziky, FHPV PU v Prešove, 2009. s. 4, ISBN 978-80-8068-961-2. [10] NĚMEC, M. Modern methods applied in teaching physics. In: Communications. Scientific letters of the university of Zilina. ISSN 1335-4205 (print)

[11] ČULÍK, M. Pythagorov monochord a štúdium kvality výsledného zvuku.

In Material - Acoustics - Place : Proceedings of the 3rd International

Symposium Material - Acoustics - Place 2007

[CD Rom]. Zvolen : Technická

Univerzita, 2007, p. 7-12. ISBN 978-80-228-

1781-3

[12] HRUŠKA, M. Integrated approach through computer-based experiments in science education. In: Information and communication technology in education. Ostrava, 2009. ISBN 978-80-7368-459-4 (print).

[13] PFEFFEROVÁ, M. The Use of Computer based Experiments in Physics Education. In: Acta Didactica 6, Nitra: FPV, 2003.

[14] TUREK, I. Didaktické testy. Kapitoly z didaktiky. Bratislava: MC 1995, s. 88. ISBN 8088796-99-7

[15] Ciel'ové požiadavky na vedomosti a zručnosti maturantov $\mathrm{z}$ fyziky - úroveň $\mathrm{A}$, [online], Bratislava: ŠPÚ, 2004. Dostupné na internete:

http://www.statpedu.sk/buxus/docs/Maturita/Cie love poziadavky/CP FYZIKA A.pdf

PaedDr. Luboš Krišt’ák, PhD.

Mgr. Miroslav Němec, PhD.

Katedra fyziky, elektrotechniky a aplikovanej mechaniky

Drevárska fakulta, Technická univerzita

Zvolen

T.G. Masaryka 24

96053 Zvolen

Tel: $+\mathbf{5 2 1 4 5 5 2 0 6 8 3 6}$

E-mail: kristak@vsld.tuzvo.sk

mnemec@acoustics.sk 